\title{
Ebola outbreak is a public health emergency of international concern, WHO warns
}

\author{
Nigel Hawkes
}

London

The World Health Organization has declared the current outbreak of Ebola virus disease in west Africa a public health emergency of international concern and has called for a strong and coordinated international response.

After a two day meeting held by teleconference, the organisation's emergency committee unanimously agreed that the outbreak - centred in Guinea, Liberia, and Sierra Leone-was "an extraordinary event and a public health risk to other states." It warned that the possible consequences of further international spread were particularly serious in view of the virulence of the virus, the fact that it had been transmitted in the community as well as in healthcare facilities, and the weak healthcare systems in the countries currently affected and those most at risk.

WHO said that, by 6 August, those three countries and Nigeria had reported 1779 cases (1134 confirmed, 452 probable, 193 suspected) and 961 deaths. This is the largest Ebola outbreak ever recorded.

At a press conference in Geneva on 8 August Keiji Fukuda, WHO's assistant director general for health security and environment, said that the causative agent was the Zaire strain of the virus, which first appeared in the 1970s. He said that the mortality rate of $55-60 \%$ was typical of that strain but that the spread this time was greater. It was too soon to say whether small genetic changes detected in the virus had made it spread more readily, he said.

WHO's declaration was accompanied by specific advice to the countries already affected, countries to which infected people may have travelled (Nigeria), and all other countries. Margaret Chan, WHO director general, said she believed that some "denial" of the seriousness of the outbreak had occurred in the three countries most directly affected and that, at a meeting with the three countries' presidents last week, she had stressed that they should treat it as a national emergency.

"I think they are beginning to do that," said Chan. She had urged them to ensure that frontline health workers were paid regularly and protected by the police and military forces if necessary, to enable them to do their work.

WHO's advice did not call for a travel ban, although some airlines have already suspended flights to the countries most affected. Chan said she did not think that a ban was justified, but the recommendations did suggest that travellers leaving the affected countries should be screened on departure for fever symptoms. She said that anyone suspected of carrying the virus should be monitored for 21 days, since the incubation period can range from 2 to 21 days.

Special attention should be focused on the Ebola "hotspot" where the three countries' borders meet, Fukuda said. In this area, the committee recommended that "quality clinical care and material and psychosocial support for the affected populations should be used as the primary basis for reducing the movement of people, but extraordinary supplemental measures such as quarantine should be used as considered necessary." Large gatherings of people should be discouraged, it added.

Recognising the limitations of the health systems in the countries involved, the committee said that establishing a strong supply pipeline was essential to ensure that sufficient medical commodities - especially personal protective equipment—were available to those who needed them, including healthcare workers, laboratory technicians, cleaning staff, burial staff, and others who may come in contact with infected people or contaminated materials.

Some changes in burial and funerary practices were also needed, Fukuda said. Funerals in west Africa frequently involved a lot of touching of bodies, he noted-providing conditions for the transfer of the virus. He said that countries should ensure that funerals were carried out safely but in a culturally sensitive way, taking into account the families' feelings. And the cross border movement of the human remains of deceased Ebola patients - whether suspected, probable, or confirmed-should be prohibited, said Fukuda, unless authorised in accordance with recognised international biosafety provisions.

Chan conceded that techniques for containing Ebola's spread were well known but that it was difficult to implement them in practice, in countries that had had civil wars in recent times. She welcomed the assistance offered by the World Bank, which has pledged $\$ 200 \mathrm{~m}$ ( $£ 119 \mathrm{~m} ; € 149 \mathrm{~m})$, and she praised healthcare providers, including Médecins Sans Frontières, for the work they were doing.

A WHO meeting next week will discuss whether novel and unlicensed treatments have anything to offer. Marie-Paule Kieny, WHO assistant director general, said, "We are in an unusual situation in this outbreak. We have a disease with a high fatality rate without any proven treatment or vaccine. We need to ask the medical ethicists to give us guidance on what the responsible thing to do is." 
Several experimental options are under development, and two health workers have been treated with one of them-raising questions about whether medicine that has never been tested and shown to be safe in people should be used in the outbreak. ${ }^{1}$ And Fukuda warned that, even if the drugs were shown to work, they were unlikely to be available in sufficient quantities, raising ethical questions about how they should be used.
1 Arie S. Ebola: an opportunity for a clinical trial? BMJ 2014;349:g4997.

Cite this as: BMJ 2014;349:95089

@ BMJ Publishing Group Ltd 2014 